\title{
Temperature, heat content, mixing and stability in Lake Orta: a pluriannual investigation
}

\author{
Walter AMBROSETTI and Luigi BARBANTI \\ C.N.R. Istituto Italiano di Idrobiologia, L.go Tonolli 50, I 28922 Verbania Pallanza, Italy \\ e-mail: w.ambrosetti@iii.to.cnr.it
}

\begin{abstract}
This paper describes the overall state of some physical phenomena occurring in Lake Orta, such as thermal stratification and destratification, accumulation and release of heat, vertical winter mixing, and stability of the water mass. The historical series of temperature distribution along the water column in the period 1984-1999, from which the holo-oligomictic character of Lake Orta emerges, is analysed. The monthly evaluation of the heat contents metre by metre from 0 to $143 \mathrm{~m}$ depth reveals how the complete winter mixing occurs only when the energy present within the whole column is less than 1,675 $\mathrm{MJ} \mathrm{m}^{-2}$; above this value the circulation is only partial, as in the other deep subalpine lakes. A water layer in the deep hypolimnion has been shown to contain a climatic memory, which has generally increased since 1981. Walker's stability analysis has revealed that when at a depth below 90 metres there is a level where $0.07 \mathrm{~J} \mathrm{~m}^{-2}$ are exceeded, total mixing cannot take place. In contrast, the Birgean work identifies, during the heating phase, the layers of the lake where energy is stored or lost.
\end{abstract}

Key words: temperature, heat content, vertical mixing, climatic memory, stability

\section{TEMPERATURE}

The response of each lake basin to external conditions (hydro-meteorological processes) is revealed in the first place by the thermal structures present in the water body. Figure 1 shows the historical series of temperature distribution along the water column in Lake Orta as the result of a series of measurements taken monthly at the deepest point $(143 \mathrm{~m})$ for the whole period from 1984-1999. The values indicated in the isotherms deliberately give more prominence to the greatest depths, detailing the temperature band below $6.5^{\circ} \mathrm{C}$; in this way we can focus on the conditions of homothermia which show the extension in depth of the winter mixing, a process that determines the temperature of the hypolimnion for the rest of the year. Thus, in February and March the isotherms of Lake Orta reveal the presence of situations of homeothermia, or near-homeothermia, though the values may differ from year to year. In the winter of 1984 the water temperature within almost the whole column was around $5.3{ }^{\circ} \mathrm{C}$, maintained, below a depth of $100 \mathrm{~m}$, for most of the year; at the end of three successive winters, however, i.e. until 1987, the same waters were found to be slightly colder, with temperatures between 5.1 and $5.3{ }^{\circ} \mathrm{C}$. Subsequently, from 1988, there began a phase of progressive heating: in February of that year the temperatures in the top 50 metres were between 5.8 and $5.9^{\circ} \mathrm{C}$, while that of the deep zone was $5.4{ }^{\circ} \mathrm{C}$, so that between bottom and surface there was a gradient of $0.5^{\circ} \mathrm{C}$ which prevented the full circulation of the lake water. Further heating was observed in the same layer of deep water in 1989 and 1990, with the temperatures rising to 5.7 and $5.8^{\circ} \mathrm{C}$ respectively. After the winters of 1991, 1992 and 1994, when isotherms around $5.8{ }^{\circ} \mathrm{C}$ were recorded, there was a perceptible winter heating over the whole water column which resulted in only partial circulations and took the temperature in the hypolimnion in the winter of 1998 to $6.5^{\circ} \mathrm{C}$. In 1999, however, there was a complete mixing, which was followed by a return to the thermal values measured at the beginning of the nineties $\left(5.8{ }^{\circ} \mathrm{C}\right)$ on the whole water column.

Figure 1 also shows how, in the thermal evolution of Lake Orta over these 16 years, during the heating phase the $5.5^{\circ} \mathrm{C}$ isotherm disappeared in 1988 , the $6.0^{\circ} \mathrm{C}$ one in 1995 and the $6.5^{\circ} \mathrm{C}$ one in August 1998, while the sudden cooling in 1999 enabled them to resurface. It should however be noted that from 1984 to 1999, despite the occurrence of 8 complete circulations, the late winter temperature of Lake Orta rose from $5.3{ }^{\circ} \mathrm{C}$ to 5.8 ${ }^{\circ} \mathrm{C}$, increasing not only its heat content but also, as we shall see, its stability.

The temperature at shallower levels shows a stable stratification with a fair degree of regularity in the seasonal thermal cycle, with the $10{ }^{\circ} \mathrm{C}$ isoline usually appearing in April and remaining until November. This layer reaches its maximum temperature, around $26^{\circ} \mathrm{C}$, in JulyAugust, and the epilimnion, which is only a few metres deep as early as May, tends to become stronger with the warm season, when the vertical thermal gradients at the level of the thermocline may in some years have values exceeding $4{ }^{\circ} \mathrm{C}$ per metre. The lower limit of the mixed layer is between 5-6 metres in July and August, and around 7-8 metres in September, after which it generally sinks as a result of the autumn cooling to settle at around 20-25 metres in December. 

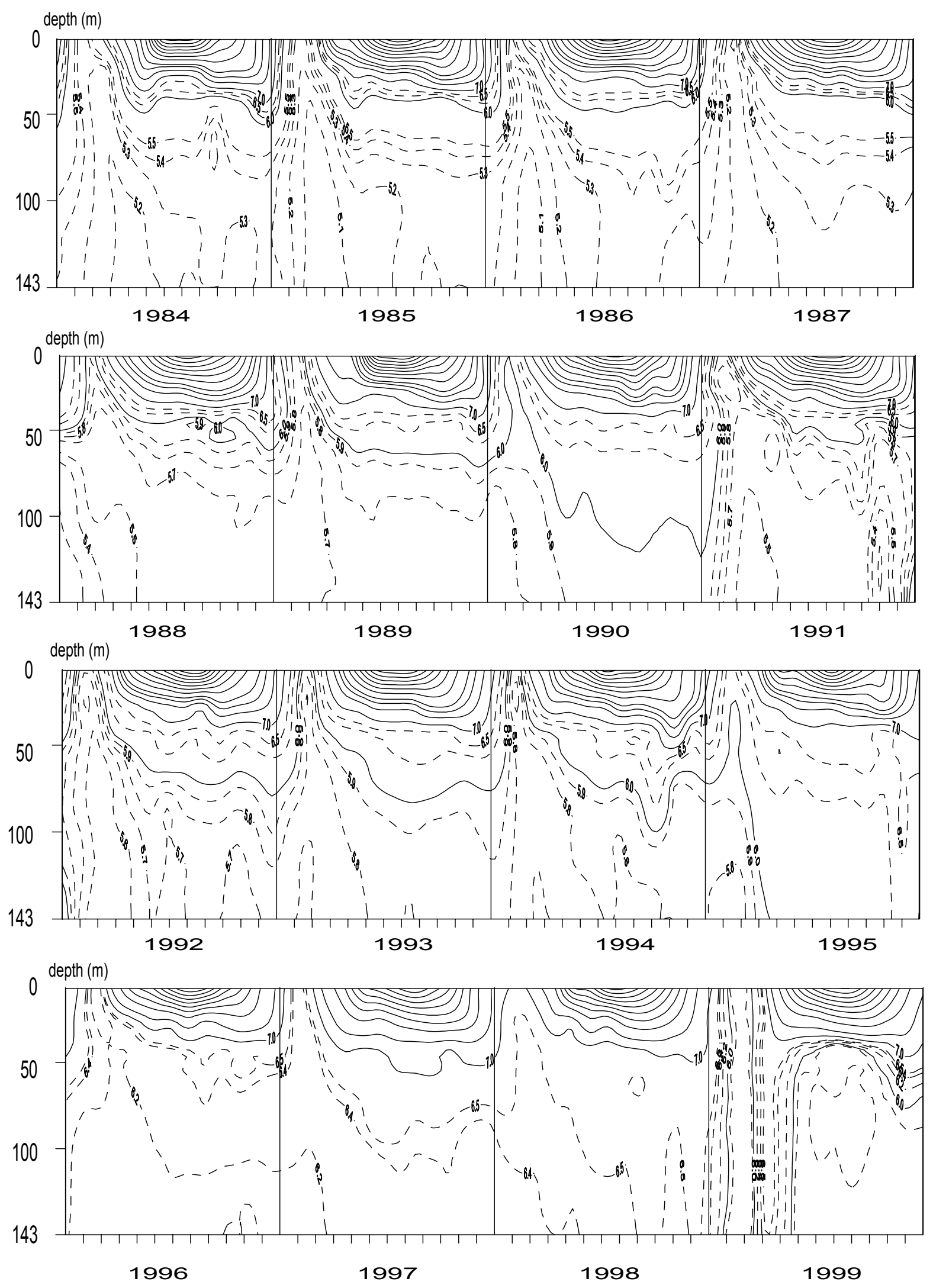

Fig. 1. Distribution of temperature in Lake Orta during 1984-1999. 
The mean depth of the epilimnion in Lake Orta in the three months of July, August and September (6.39 $\mathrm{m})$ is at first sight in line with that of the other deep subalpine lakes: Como $7.72 \mathrm{~m}$, Maggiore $6.92 \mathrm{~m}$, Garda $9.96 \mathrm{~m}$, Iseo $5.29 \mathrm{~m}$ and Lugano North Basin 6.29. However, it should be noted that these lakes are all subject to a much higher fetch than Lake Orta, even more than twice as high in the case of the first four. This means that it is easier for the wind to produce a more stable summer mixed layer in Lake Orta.

The Lake Orta thermocline reaches on average depths of 6.7, 7.97 and 11.3 metres respectively in July, August and September, and, among the deep valley lakes, is the one which has on average the highest heat gradients $\left(2.93,3.07\right.$ and $2.73^{\circ} \mathrm{C}$ in those months). The mean daily depth of the thermocline from 1 July to 30 September can be calculated using the equation:

$$
\mathrm{y}=0.054 \mathrm{x}+5.81
$$

where $\mathrm{x}$ is the number of days starting from July (Pompilio et al. 1996). In December a weak gradient is still present, on average at a depth of around 25-30 metres.

\section{HEAT CONTENT}

The vertical distribution of heat content in Lake Orta was calculated monthly from the pluriannual data of the water temperature for the years specified above. We used the LIMNOX programme (Banens 1988) which makes it possible to determine the total quantity, as well as the metre by metre distribution, from surface to bottom, of the heat content, the Schmidt \& Walker stabilities, and the Birge work.

The monthly trend of the heat content in Lake Orta is given in figure 2, which shows clearly that, in addition to the seasonal cycle which is very variable in its maximum and minimum values, there is also a general trend of the series which has been increasing, especially since the nineties. The minimum values, which are normally found in February and March, are between 1498 MJ m$~^{-2}$ (1985) and $1907 \mathrm{MJ} \mathrm{m}^{-2}$ (1998), while the highest values (August-September) are between 2393 $\mathrm{MJ} \mathrm{m}^{-2}$ (1981) and $2950 \mathrm{MJ} \mathrm{m}^{-2}$ (1997).

The maximum annual heat contents $\left(\mathrm{Q}_{\mathrm{tmax}}\right)$ in Lake Orta are shown in figure 3 in which, besides the general rising trend, the considerable increases in 1990 and 1997, as well as the decreases in 1991, 1998 and 1999, are quite clear. The same figure shows that the minimum winter values $\left(Q_{\text {tmin }}\right)$, on the other hand, have a more linear trend, very similar to those of the maxima up to 1991, then rising steadily up to 1998 , to fall sharply in 1999. Their values are below $1675 \mathrm{MJ} \mathrm{m}^{-2}$ up to 1987, but also in 1991, 1992 and 1994, coinciding with the occurrence of full circulation in the lake (see below).

The annual heat budget series $\left(\mathrm{B}_{\mathrm{t}}\right)$, always represented in figure 3 by the thinnest line, shows in contrast an oscillating trend, almost identical to that of the maximum heat content $\left(\mathrm{Q}_{\mathrm{tmax}}\right)$ and the opposite, except for the period 1988-1992, of the trend of the minimum winter content $\left(\mathrm{Q}_{\mathrm{tmin}}\right)$. There is in fact a strict correlation between $\mathrm{B}_{\mathrm{t}}$ and $\mathrm{Q}_{\mathrm{tmax}}(\mathrm{r}=0.80)$, while the correlation between $B_{t}$ and Qtmin is not significant. As the energy budget in Lake Orta is strictly dependent on the quantity of heat which from the end of the limnological winter is stored and distributed almost exclusively in the surface layers (Ambrosetti \& Barbanti 1999), we decided to evaluate the depths at which the heat exchange takes place by presenting them in percentage values of the exchange itself (Fig. 4).

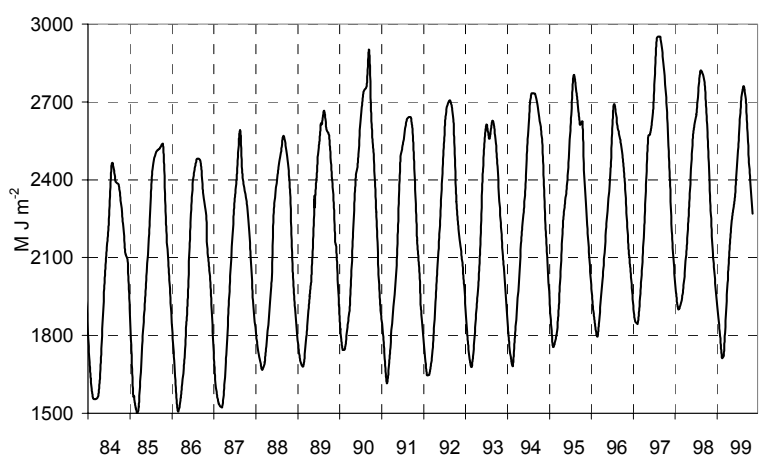

Fig. 2. Trend of total heat content in the Lake Orta water column, based on monthly data, during the period 1984-1999.

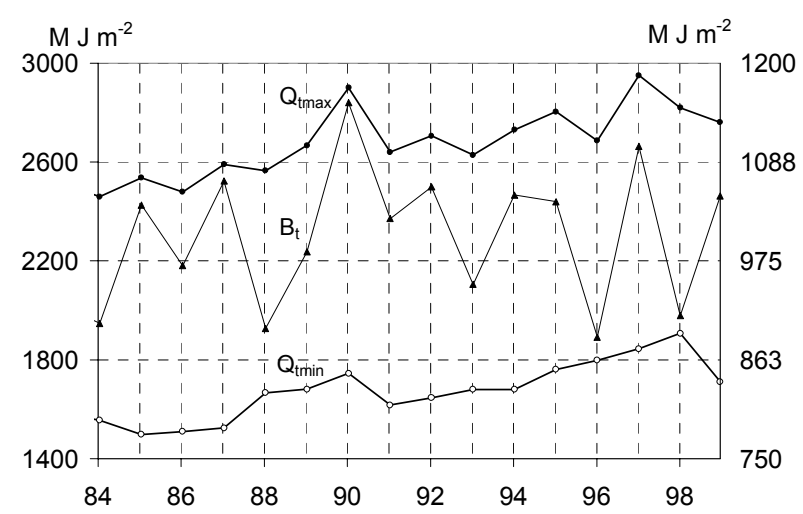

Fig. 3. Annual maximum and minimum heat content and heat budget in Lake Orta during 1984-1999. The heat budget values refer to the right axis.

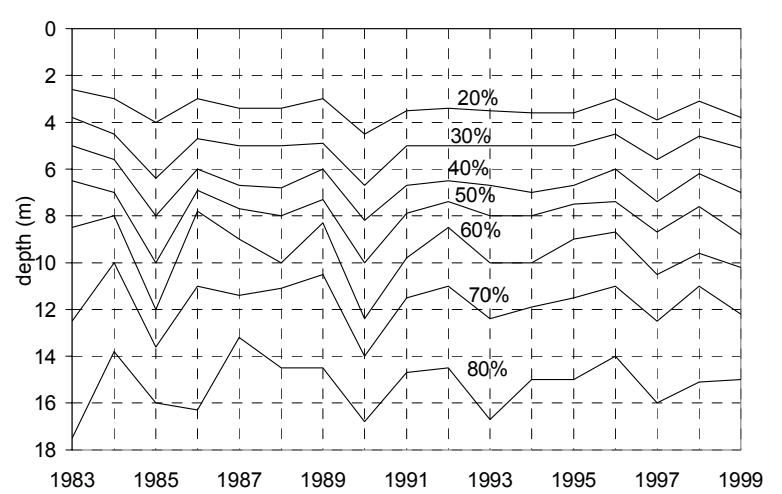

Fig. 4. Trend of depths of different percentage exchanges of heat in Lake Orta (depth limited to top $18 \mathrm{~m}$ ). 


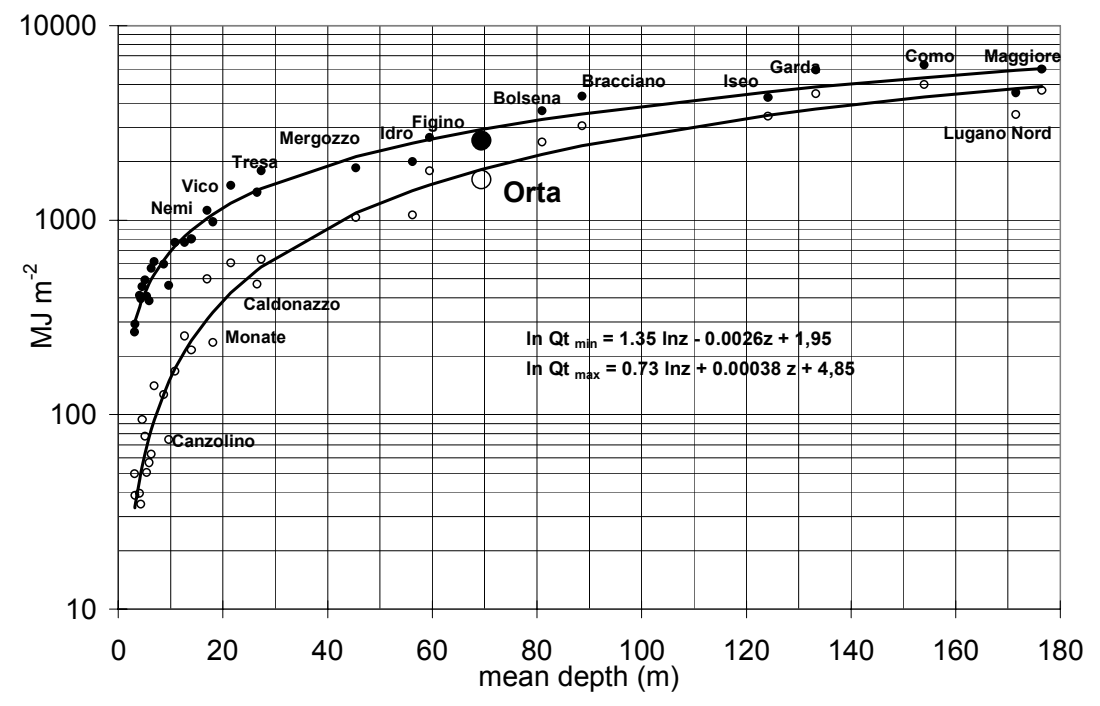

Fig. 5. Graph and equation showing the relationship of maximum and minimum heat $\left(\mathrm{Q}_{\mathrm{t}}\right)$ to mean depth $\left(\mathrm{z}_{\mathrm{m}}\right)$ in 31 Italian lakes.
It emerges very clearly that $80 \%$ of the heat is stored in the top 18 metres, i.e. a very limited thickness compared with the 143 metres of the depth of the lake.

It should also be noted that in years such as 1985 , 1990 and 1997 the curves dip significantly (by about 3$4 \mathrm{~m}$ ): these are years when the $B_{t}$ values were high, an indication that a greater volume of surface water was heated, with a consequently greater storage of heat. This mechanism is fostered by the fact that in the years when the surface exchange is high, the thermocline is already forming at the beginning of May, with gradients higher than one degree per metre, defining a layer of between 4 and 8 metres: i.e. much earlier and deeper than in other years. This situation makes it easier for the wind to trigger the double epi-hypolimnic circuit of the currents, typical of stratified lakes. As on Lake Orta the spring and early summer months are characterised by very windy conditions, the surface currents reach their highest speeds of the whole year (on average around 8.0 $\mathrm{s}^{-1}$ at the surface); the not very deep epilimnetic layer is easily set in motion by the wind (Ambrosetti \& Barbanti 1990). The double circulation is also helped by the particular conformation of Lake Orta, which gives the wind a wide part of the surface which can be blown over without obstacles (Pompilio et al. 1996). The development of an appreciable shear at thermocline level thus makes possible a relative deepening of the epilimnion and increases the heat content in the top section of the lake.

During years in which the thermal budget remains at low levels, as for example in 1988, the thermocline is absent in May, still unstable in June, and in July presents a gradient of $1.8^{\circ} \mathrm{C}$ per metre, far less than the values for the years of high $B_{t}$.

When the heat content is greatest (August-September), the eplimnion of Lake Orta is perfectly mixed, and reaches a maximum of 12-14 metres in the years of high energy budget. In contrast, the vertical heat distribution at the moment of the maximum energy content does not show a clear thermal stratification in the years of lower $\mathrm{B}_{\mathrm{t}}$.

As previous studies have demonstrated (Gorham 1964; Green et al. 1987; Ferris \& Burton 1988; Henry \& Barbosa 1989; Geller 1992), the maximum and minimum heat contents and consequently the heat budgets of lakes in various parts of the world are strictly dependent on their morphometric parameters (volume, mean or maximum depth). This has also been verified for 31 Italian lakes of varying depths, in which, as may be seen in figure 5, the maximum and minimum heat contents are related to their mean depth through a multiple linear regression, expressed in the figure in logarithmic terms. Lake Orta, with a mean depth of $69.4 \mathrm{~m}$, is slightly below the curve; it should be remembered that in the 16 years considered its minimum and maximum energy contents have $\mathrm{CV}$ values of 7.07 and 5.27 respectively.

\section{VERTICAL MIXING}

As Lake Orta is the shallowest of the great subalpine lakes $(143 \mathrm{~m})$, it used to be thought to undergo only late winter vertical mixings of the holomictic type. However, research on the hydrodynamics of Orta by Ambrosetti \& Barbanti $(1990,1993)$ and Barbanti et al.(1996) showed that the lake may not infrequently undergo only partial mixings, so that it would be more correctly described as holo-oligomictic, as are the other large lakes of northern Italy.

The oligomictic events of Lake Orta during the last fifteen years have also been analysed using the same numerical parameter applied successfully to Lago Maggiore (Ambrosetti \& Barbanti 1999); this adimensional parameter (M) has been evaluated considering the values of water temperature and meteorological factors responsible for the buoyancy and/or mixing of the lake (solar radiation, air temperature and wind) appropriately weighted for the winter months (December, January and February). 
As there is no meteorological station in operation on Lake Orta, we used data recorded at the station of the Istituto Italiano di Idrobiologia in Pallanza, which can also be considered valid for the lake; the distance between the two locations as the crow flies is about fifteen kilometres, but the regional meteorological picture is sufficiently similar, especially at the anemological level. Measurements taken directly in the lake were used for the data referring to the heat of the lake required by the formula proposed.

The values of the parameter $M$ show that the winter mixing resulting from convective motion in Lake Orta involved the whole volume of the lake in the years from 1984 to 1987, followed by three years (1988-1990) when the vertical circulation did not reach the maximum depth; after this there were alternate phases of holomixis and oligomixis (Fig. 6). The depths reached by the winter mixing, evaluated using the model described above, in most cases coincide with the depths verified by an analysis of the vertical distribution of the chemical parameters. The sole exception is 1997, when other kinds of mechanism, already found in Lago Maggiore, probably occurred at the same time as the limnological winter (Ambrosetti et al. 1982; Ambrosetti \& Barbanti 1999; Ambrosetti \& Barbanti 2000; Barbanti \& Ambrosetti 1990). These mechanisms generally cause the most oxygenated surface water to sink to the deep layers, with a consequent change in the chemical-physical structure of the hypolimnion. In the specific case of Lake Orta, it is possible that the water in the much shallower southern basin (south of the Island of San Giulio), being subject to more rapid cooling, sinks in the central basin.

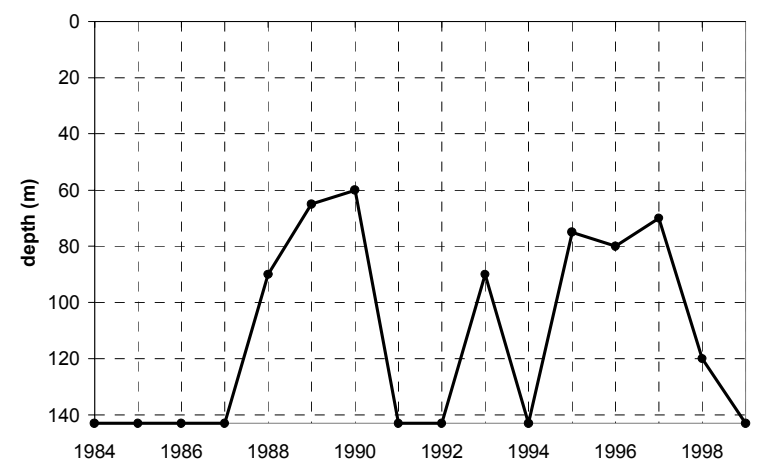

Fig. 6. Depths of vertical mixing in Lake Orta at the end of the limnological winter during the period 1984-1999.

\section{RELATIONSHIP BETWEEN MIXING AND HEAT CONTENT}

We have already mentioned the close relationship which exists between the minimum heat content in the year and the depth reached by the winter mixing. A more detailed analysis reveals that the two historic series of the respective data (1984-1999) had a very similar trend until 1987; these years were characterised by complete vertical circulations with the Qt at almost steady values, between 1508 and $1550 \mathrm{MJ} \mathrm{m}^{-2}$. But from 1988 to 1990 , when the circulations were partial, the total energy content of the lake increased considerably, reaching $1742 \mathrm{MJ} \mathrm{m}^{-2}$, and after a slight reduction in 1991 and 1992, continued rising, to exceed $1905 \mathrm{MJ} \mathrm{m}^{-2}$ in 1998. In 1999, however, there was the last full circulation event in the lake, and the total winter heat content fell to values of just over $1675 \mathrm{MJ} \mathrm{m}^{-2}$.

The oldest historical data available to us (since 1960), though not continuous, show that up to 1989 values greater than $1675 \mathrm{MJ} \mathrm{m}^{-2}$ were not recorded. The phase of steadily increasing heat up to 1998 (apart from 1991 and 1992, when no increase was recorded) reveals a most important fact: that the complete circulations, intercalated with the partial mixings, did not succeed in bringing the lake back to its initial energy situation, i.e. that of the seventies, and that the successive complete circulation events occurred in the presence of increasingly high heat contents. This means that external forces were not able to bring the ecosystem back to its initial energy situation and overcome the energy potential contained in the water mass; this is testified to by the increase in the water temperature referred to above. In Lago Maggiore, this heating, which has occurred mainly over the last ten years, has been linked (Ambrosetti \& Barbanti 1999) to the greater increase in the temperature of the atmosphere than of the surface water, and a decrease in the daily wind run. In fact, in this area after 1974 there was a drop in the winter wind run from 2000 to $700 \mathrm{~km}$, while the air temperature over the last decade has shown a mean increase of $0.046^{\circ} \mathrm{C}^{-1}$, compared with the $0.015{ }^{\circ} \mathrm{C} \mathrm{y}^{-1}$ of the previous twenty years. Similar situations undoubtedly arose in Lake Orta.

As regards the maximum values of the monthly heat content, only those relating to 1991 and 1999 depend on the depth of the winter mixing (in both years there was a complete overturn). These values (Fig. 2) are recorded between August and October and increase steadily and steeply over the years, with a peak in September 1997 $\left(2950 \mathrm{MJ} \mathrm{m}^{-2}\right)$. On that occasion the mean spring and summer atmospheric temperature showed a marked increase compared with the mean of the considered period. It therefore appears that the annual energy maximum depends in most cases on the immediately preceding meteorological situation and not on the winter hydrodynamics. In this sense Orta may be considered a lake of transition between the deep lakes whose heat content depends on the winter mixing, and shallower lakes which are to a greater extent subject to the action of external factors.

\section{CLIMATIC MEMORY}

As has been found in the other large subalpine lakes, the temperature of the hypolimnic waters of Lake Orta has been steadily increasing in time, with this heating particularly evident at the moment of the winter circula- 
tion. We have seen how the 1984 temperatures of 5.1$5.2{ }^{\circ} \mathrm{C}$ increased gradually to $6.4-6.5{ }^{\circ} \mathrm{C}$ in 1998 (maximum temperature), returning to $5.8-5.9{ }^{\circ} \mathrm{C}$ in 1999 . The consequence has been a marked storage of energy within this layer. It should be remembered that Orta undergoes a greater degree of winter cooling than do the other deep lakes, as its maximum depth is little more than a third of that of the others.

In the same way as Ambrosetti \& Barbanti (1999 and 2000) had already done for the other lakes, they identified in the deep hypolimnion a water layer whose energy content represents the so-called climatic memory. Its value was determined in its position in space and time, and in the extent of its energy, on the basis of different hydrodynamic conditions: depth of the winter mixing, metre by metre heat exchanges at depth, and correlation of logarithmic values of the coefficients of vertical turbulent diffusion $\left(\mathrm{K}_{\mathrm{z}}\right)$ vs those of Brunt Väisälä's frequency $\left(\mathrm{N}^{2}\right)$ during the summer stratification (Michalsky \& Lemmin 1995). The trend in time of this memory is shown in figure 7. The energy, and therefore thermal, characteristics of this layer, between 70 and $143 \mathrm{~m}$ depth, do not follow the seasonal variations found in the whole water mass (Fig. 2), while a general increase since 1981 is evident. The sudden changes, which are clearly seen on the curve, are justified by the presence of apparently anomalous meteorological and hydrological events, which have affected the lake water differently both in the past and in more recent years.

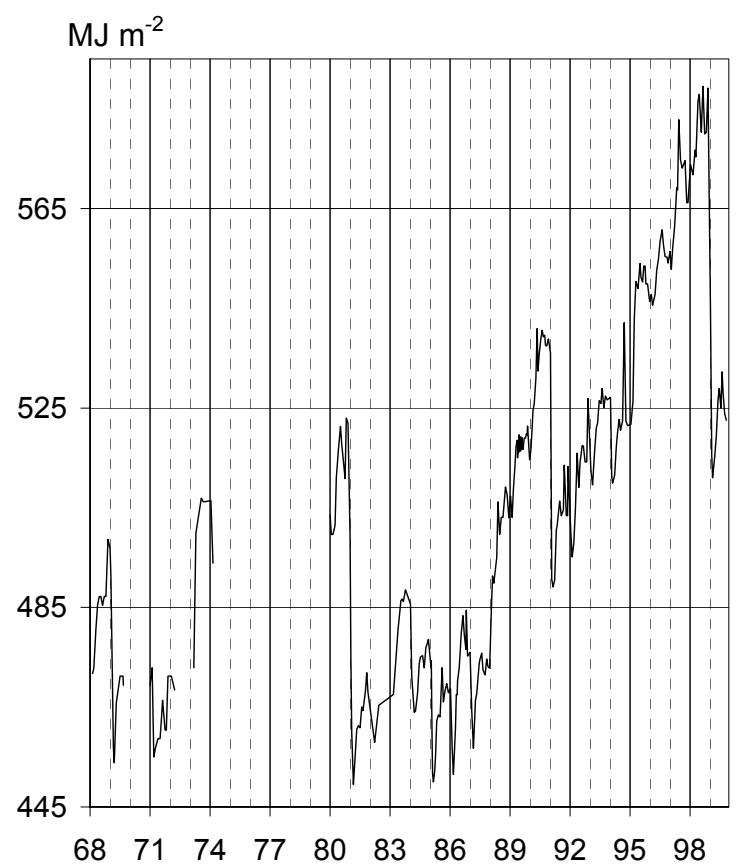

Fig. 7. Trend of heat content in the climatic memory of Lake Orta, based on data measured at monthly intervals.

The heat content in the climatic memory of Lake Orta reveals trends similar to those found in Lago Mag- giore and Lake Garda (Ambrosetti \& Barbanti 1999), with the greatest variations, in a negative as in a positive sense, whether wide or limited, seen at the same time. However, Lake Orta, which is much shallower than the other two and has no tributaries of great volume, lacks the input of cold, oxygenated water, or water which is warmer but very dense because of suspended solutes, which can determine profound changes in the thermal structure of the hypolimnion. Consequently its energy content in the deep layer is dependent largely on the combined action of wind and atmospheric temperature, which can give rise to particular conveyor-belt currents in the lake (Ambrosetti et al. 1982), or also to processes of mixing through convective motions, or again, to the already mentioned possibility of colder water coming from the southern basin and sinking. It follows that of the major negative changes in the climatic memory highlighted in figure 7 , that of 1981 is to be ascribed to the first of the above described mechanisms, while for the other years it is more difficult to ascribe the changes to any one of the possible causes; it is more likely that there was a synergetic action of the various mechanisms.

Finally, the increases and decreases of the climatic memory in Lake Orta are more in evidence than they are in Garda and Maggiore; Orta being a shallower lake, a lower amount of energy is required for a complete circulation of its water than is the case in the deeper lakes. This means that every mixing event in Lake Orta involves a greater degree of cooling in the deep layers, which however is not sufficient to invert the positive trend in evidence since 1981.

\section{STABILITY AND BIRGEAN WIND WORK}

Again taking as our starting point the data collected on Lake Orta since 1984, we also evaluated the thermal stability (sensu both Schmidt and Walker) and the Birgean wind work (Bowling 1990; Johnson et al. 1978), considered apart from their incidence linked to hydrostatic pressure. The first parameter (S) is an estimate of the amount of work required to mix a thermally stratified lake so as to reach a new isothermal state without gaining or losing heat. In contrast, the work of the wind (B) is the amount of external energy (both mechanical and non-mechanical) required to produce a certain thermal stratification in a lake, without taking into account the mechanisms by which this energy enters the lake. In fact, the energy supply is not confined to the work of the wind alone, but may be linked to crossflows which can assume fundamental importance both in determining and in preventing thermal stratification.

These parameters of stability have been dealt with at length by Hutchinson (1957), and are for comparing and contrasting the physical background of various lake environments, although they are seldom calculated and employed as limnological working tools (Johnson et al. 1978; Bowling 1990). 


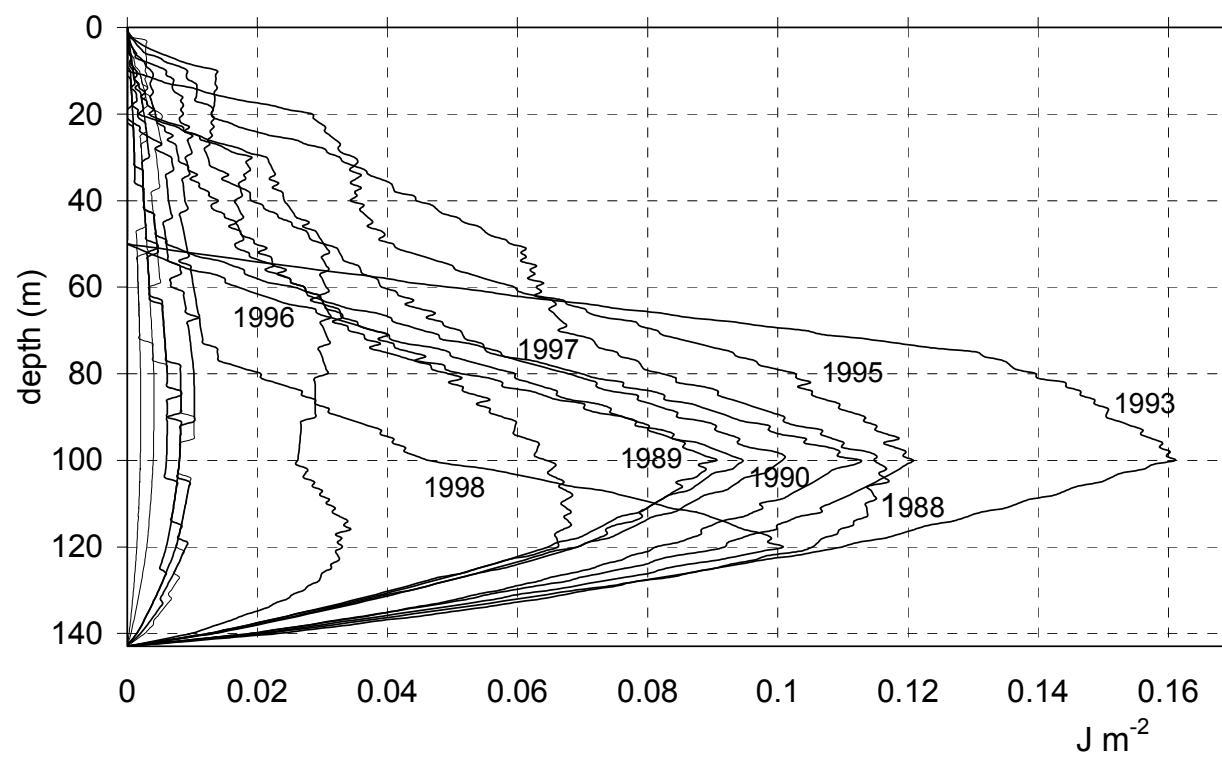

Fig. 8. Vertical stability sensu Walker in Lake Orta at the end of the limnological winter from 1984 to 1999.

The annual S values calculated for Lake Orta generally follow the changes in heat content, varying with the degree of thermal stratification present, though maximum stability and maximum heat content may not necessarily coincide. The work of the wind also undergoes annual variations similar to those of the other two parameters, with a maximum in autumn and a minimum in winter. The $\mathrm{S}$ values, as is usually the case in deep lakes, are greater than the B values, as more work is required to break up the thermal stratification present than is needed to distribute to the deep layers the heat entering the lake.

These parameters can be evaluated as a total on the whole water column (which allows a comparative analysis with other lakes), or they can be analysed in their vertical distribution along the water column. The latter values can be used to verify the hydrodynamic mechanisms occurring within the water mass of a single lake.

The first type of evaluation shows that in Lago Maggiore the two stabilities and the maximum Birgean work of the year are respectively 3 and 5 times higher than they are in Orta (Barbanti \& Ambrosetti 1986).

The vertical distribution of stability sensu Walker at the presumed moment of maximum winter circulation, on the other hand, makes it possible to confirm what was stated above about the depth reached by mixing in Lake Orta from 1984 to 1999.

In figure 8 it can be seen that eight of the sixteen curves relating to the limnological winter of each year show a peak of between 90 and $120 \mathrm{~m}$ depth, which not only confirms the years when there was not a complete homogenisation of the lake water, but also the depths previously evaluated both by the parameter $\mathrm{M}$ and by the chemical data and energy contents. Furthermore, the same curves clearly reveal the deep water layers in Lake
Orta which offer the greatest resistance to vertical mixing.

The figure also highlights how in Lake Orta, as in the other deep lakes, a thermal difference of a few tenths of a degree may determine stability values at the various levels of the water mass to the extent that, though they may be quite small, they can be sufficient to prevent a complete mixing. On the basis of the values given in the figure, it may be stated that whenever a stability of over $0.07 \mathrm{~J} \mathrm{~m}^{-2}$ is still present at a depth below $90 \mathrm{~m}$ in the winter, a complete overturn does not occur.

A comparison with the values which have prevented mixing in Lago Maggiore for the last 28 years (with consequent partial winter mixing depths confined to between 50 and 150 metres) shows that the Lago Maggiore values are 10 times higher; for example, the stabilities sensu Walker are between 0.6 and $1.2 \mathrm{~J} \mathrm{~m}^{-2}$.

In contrast, the vertical distribution at the moment of the maximum stability of the year presents peaks at depths between 15 and 20 metres: the minimum in 1993 , with $9.47 \mathrm{~J} \mathrm{~m}^{-2}$, and the maximum in 1987 , with $12.84 \mathrm{~J} \mathrm{~m}^{-2}$, corresponding to the depth of the thermocline.

Further important considerations on the processes intervening in the water mass may also be inferred from the evaluation of the differences found between the values of the Birgean work $(\Delta \mathrm{B})$ at the same depth on two successive dates of thermal records. Their temporal variation provides information about the sign to be ascribed to this value, which may be explained both as the action of the external environment on the lake and as the release of the lake's energy towards the surrounding environment. In both cases the vertical distribution of $\Delta B$, with its own negative or positive values, makes it possible to establish the depths at which energy is each time released or taken up (Fig. 9). This figure contrasts the variations in $\mathrm{B}$ during the period of thermal stratifica- 

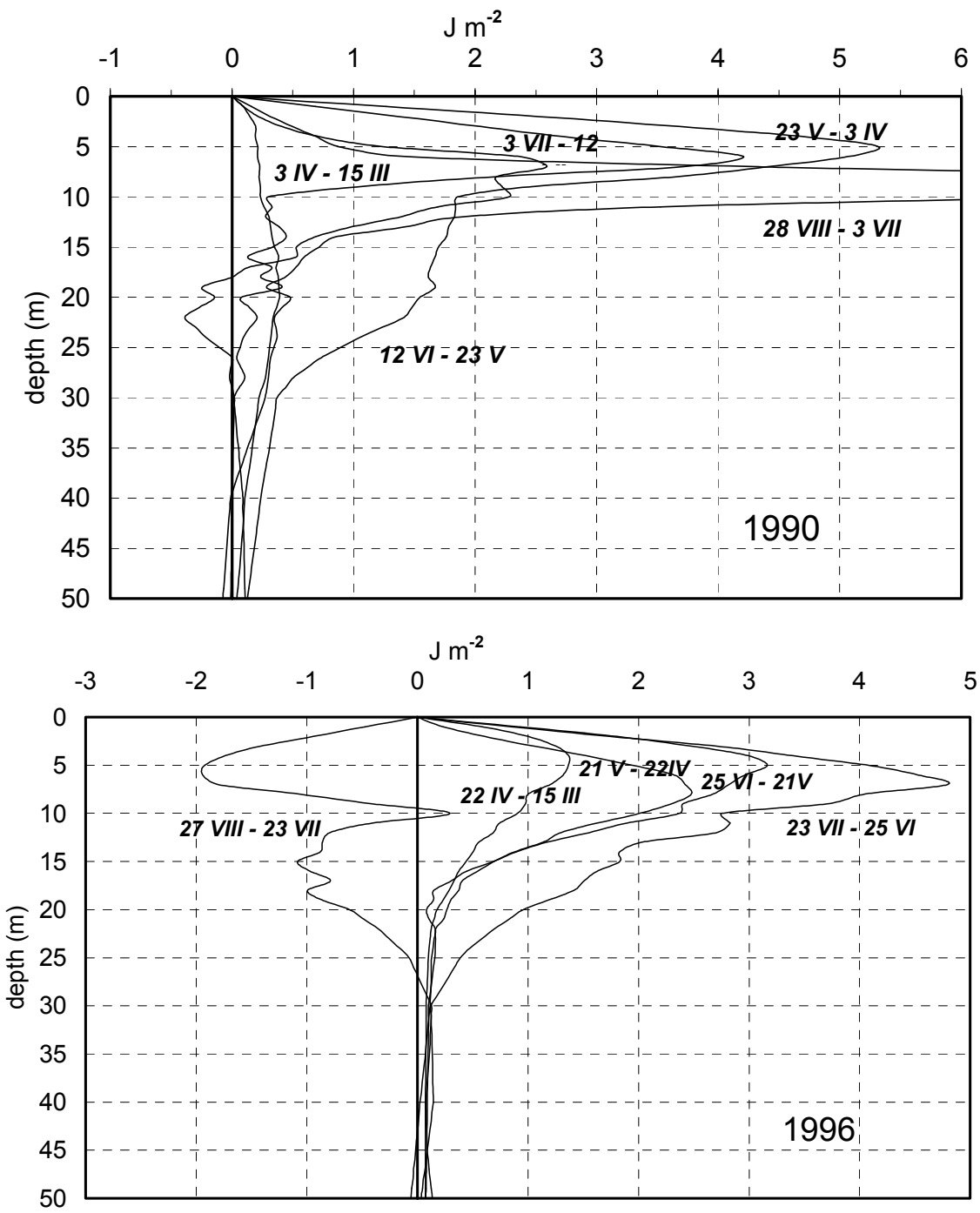

Fig. 9. Variations of the Birgean work $(\Delta \mathrm{B})$ during the heating phase in Lake Orta in 1990 and 1996. tion in 1990 and 1996, which are the years with respectively the highest and lowest thermal budgets of the historic series. Bearing in mind that the time intervals between one measurement and the other are not the same in both years, from the analysis of the curves in the figure (limited to the top 50 metres of the lake) we can see that in 1990 (high thermal budget) the external action on the surface layers appears to be most intense in April, May and June, and increases more and more until the top $20 \mathrm{~m}$ are affected; between July and August there is still an intense external action with considerable influence on the lake, so that $10.8 \mathrm{~J} \mathrm{~m}^{-2}$ are reached at around $-10 \mathrm{~m}$, with a consequent marked storage of heat. In the same months (July and August) of 1996, on the other hand, the $\Delta \mathrm{B}$ values become negative, indicating a loss of heat from the lake, a situation which usually occurs in September.

The explanation of the different behaviour of the two years lies in their different meteorological situations. In the 16 year series of the study, 1996 was cha- racterised by a very low mean summer atmospheric temperature $\left(21.62^{\circ} \mathrm{C}\right)$, higher only than that of 1987 , and by a spring temperature with medium low values $\left(12.25^{\circ} \mathrm{C}\right)$. In contrast, the 1990 spring temperature reached a maximum for the season of $13.56^{\circ} \mathrm{C}$, and in the summer, with $22.19{ }^{\circ} \mathrm{C}$, reached medium high values. In addition, the mean monthly temperature in August 1990 was $23.14^{\circ} \mathrm{C}$ (third highest value in the 16 years), much higher than that of 1996 , which was only $21.37{ }^{\circ} \mathrm{C}$, among the lowest values for that month of the last 16 years. Finally, it should be noted that the wind run in the summer of $1990(3905 \mathrm{~km})$ was $27 \%$ higher than that of 1996.

\section{CONCLUSIONS}

One of the aims of this study was to verify the reciprocal relationships existing between the limnological situation, i.e. within the lake, and external meteorological conditions, which are easier to define in quantitative terms, in so far as they refer to the main atmospheric pa- 
rameters. There remained the necessity, which had emerged on more than one occasion, particularly at the stage of statistical correlation between the two series of data, of describing aspects of lake hydrodynamics, at least the most important, in terms of numerical parameters. In this connection it seemed useful to use the standard parameters quantifying the energy of a lake, i.e. heat contents, stability and Birgean work. These parameters proved to be particularly useful for understanding the complex hydrodynamic processes occurring in Lake Orta, such as winter vertical mixing, resistance to mixing, internal stability of the water mass, and made it possible to describe them also in quantitative terms.

The determination on a monthly basis of the total heat contents on the water column and at the various levels of the water mass made it possible to establish the energy levels within which a winter mixing may take place, and to understand how the annual heat budget of the lake depends on the quantity of heat which has accumulated during the stratification period, and on the thickness of the surface layer of the lake involved in the mixing. We evaluated the relationship existing between winter meteorological parameters and mixing depth, as well as the amount of heat contained in the deep hypolimnion, i.e. the layer containing the climatic memory; the trend of the climatic memory is in strict relationship with the meteorological and hydrological events, especially the anomalous ones, occurring within the lake basin. Stability and Birgean work made it possible to confirm, again in quantitative terms, the depths reached by the winter mixing, which we also determined using other methods, and to define which of the layers of the surface part of the lake's water mass store or release heat to the atmosphere during the summer.

Taken as a whole, the results of these investigations have made a very useful contribution, also in quantitative terms, to our understanding of some important phenomena in Lake Orta. Apart from their use in analysing purely physical processes, in particular the relationships between hydrodynamic characteristics and triggering factors, these energy parameters can be of considerable interest for studies involving the chemical and biological compartments of the lake ecosystem.

\section{REFERENCES}

Ambrosetti,W. \& L. Barbanti. 2000. Riscaldamento delle acque profonde nei laghi italiani: un indicatore di cambiamenti climatici? Acqua \& Aria, 4: 65-72.
Ambrosetti,W. \& L. Barbanti. 1999. Deep water warming in lakes: an indicator of climatic change. J. Limnol., (58): 19.

Ambrosetti,W. \& L. Barbanti. 1993. Heat content and vertical mixing in Lake Orta. Mem. Ist. ital. Idrobiol., 51: 1-10.

Ambrosetti,W. \& L. Barbanti. 1990. Evidenza di situazioni olo-oligomittiche nel Lago d'Orta. Atti $9^{\circ}$ Congr. A.I.O.L.: 433-444.

Ambrosetti,W. \& L. Barbanti. 1990. Idrodinamica del Lago d'Orta. In: Bonacina, C., A. Calderoni \& R. de Bernardi (Eds), Ricerche limnologiche sul Lago d'Orta finalizzate al suo risanamento. Documenta Ist. ital. Idrobiol., 28: 3-8.

Ambrosetti,W., L. Barbanti \& R. Mosello. 1982. Unusual deep mixing of Lago Maggiore during the winter 1980-1981. Geogr. Fis. Dinam. Quat., 5:183-191.

Banens, Bob.1988. Programma LIMNO modified and adapted for MS-Dos 3.2 and QUICKBASIC by Bob Banens. University of New England, Armidale NSW. Australia.

Barbanti L., W. Ambrosetti \& L. Pompilio.1996. Morphometry and thermal stratification in Italian lakes. 2. The "Depth Ratio" as a predictive index of thermal structures. Mem. Ist. ital. Idrobiol., 54: 31-42.

Barbanti L. \& W. Ambrosetti.1990. The physical limnology on Lago Maggiore: a review. Mem. Ist. ital. Idrobiol., 46: 47-78.

Barbanti L. \& W. Ambrosetti.1986. Energia termica e stabilità meccanica nel Lago Maggiore. Atti del $7^{\circ}$ Congr. A.I.O.L.: 119-132.

Bowling, L.C. 1990. Heat content, thermal stabilities and birgean wind work in distrophic Tasmanian Lakes and Resevoirs. Aust. J. Freshwater. Res., 41. 429-441.

Ferris, J.M. \& H.R. Burton. 1988. The annual cycle of heat content and mechanical stability of hypersaline Deep Lake, Vestfold Hill, Antartica. Hydrobiologia, 165: 115128.

Geller, W. 1992. The temperature stratification and related characteristic of Chilean lakes in midsummer. Acquatic Sciences, 54: 37-57.

Ghoram, E. 1964. Morphometric control of annual heat budget in temperate lakes. Limnol. Oceanogr., 9: 525-529.

Grenn, J.D., A.B. Viner \& D.J. Lowe. 1987. The effect of climate om lake mixing petterns and temperatures. In: A.B. Viner (Ed.), Inland Waters of New Zealand: 65-95.

Henry, R. \& F.A.R. Barbosa. 1989. Thermal structure, heat content and stability of two lakes in The National Park of Rio Doce Valley (Minas Gerais, Brazil). Hydrobiologia, 171: 189-199.

Hutchinson, G.E. 1957. A treatise on limnology. Vol I. John Wiley and Sons. New York: $1015 \mathrm{pp}$.

Johnson, N.M., J.E. Eaton \& J.E. Richey. 1978 Analysis of five North American lake ecosystem. II. Thermal energy and mechanical stability. Verh. int.Ver. Limnol., 20: 562567.

Michalsky, J. \& U. Lemmin.1995 Dynamics of vertical mixing in the hypolimnion of a deep lake: Lake Geneva. Limnol. Oceanogr., 40: 809-816.

Pompilio, L., W. Ambrosetti \& L. Barbanti. 1996. Morphometry and thermal stratification in Italian lakes. 1. Predictive models. Mem. Ist. ital. Idrobiol., 54: 1-29. 